\title{
Bioactive Alkaloids from South American Psychotria and Related Species
}

\author{
Diogo D. Porto ${ }^{1}$, Amélia T. Henriques ${ }^{2}$ and Arthur G. Fett-Neto ${ }^{1,3, *}$ \\ ${ }^{I}$ Centro de Biotecnologia, Universidade Federal do Rio Grande do Sul, Brazil \\ ${ }^{2}$ Faculdade de Farmácia, Universidade Federal do Rio Grande do Sul, Brazil \\ ${ }^{3}$ Departamento de Botânica, Universidade Federal do Rio Grande do Sul, Brazil
}

\begin{abstract}
Many important molecules have been discovered from tropical and sub-tropical plant biodiversity. However, the largest part of the chemical profile of such biodiversity remains unknown. Combining ethnopharmacological and chemotaxonomical investigation can be a good strategy in bioactive compound discovery. South American Psychotria species studied by this approach proved to be a rich source of new bioactive alkaloids, some of which bear unique chemical skeletons.
\end{abstract}

Key Words: Alkaloids, South America, Psychotria, Ethnopharmacology, Analgesic.

\section{INTRODUCTION}

Plants synthesize an extensive array of secondary metabolites, or natural products, and many of them have pharmacological properties. These bioactive compounds can be found in plants traditionally used for medical purposes, i.e. medicinal plants. Extracts, infusions and other preparations from medicinal plants were the sole alternative to human healthcare needs until the nineteenth century [1]. The isolation of morphine in 1806 is regarded by many as the beginning of phytochemistry $[2,3]$. From then on, the development of organic chemistry provided standardized medications through synthethic drugs and active compounds isolated from biological material.

Despite being complex and expensive, biodiversityscreening programs remain productive approaches in drug discovery [4]. Between 1981 and 2006, 36\% of all small molecule new chemical entities were natural products or derived from them, usually by semisynthethic modification [5]. Other $24 \%$ were "natural product mimics", i.e. competitive inhibitors of natural substrates. High throughput screening techniques [6] as well as advancements in biochemistry and biotechnology of secondary metabolism [7-9] are major contemporary achievements which are accelerating natural products research.

This review focuses on molecules found in Rubiaceae plants that have been evaluated for their bioactivity. To that end, a systematic search for full length articles was carried out in indexed databases (e.g. Science Citation Index Expanded $^{\circledR}$ ), highlighting alkaloids discovered within the last decade from South American Psychotria species of the Atlantic Forest biome.

*Address correspondence to this author at the Center for Biotechnology, Federal University of Rio Grande do Sul, P.O Box 15005, Porto Alegre, RS, Brazil, Postal Code: 91501-970, Brazil; Tel: 55513308 7642; Fax: 5551 3308 7309; E-mail: fettneto@cbiot.ufrgs.br

\section{ACTIVE ALKALOIDS FROM RUBIACEAE PLANTS}

The Rubiaceae, a large plant family with 10,700 species [10], yielded the most widely used human stimulant, caffeine (reviewed in Ashihara et al. [11]). Novel active structures, belonging to diverse biochemical classes such as alkaloids [12-15], anthraquinones [15-17] and peptides [16, 18, 19] are constantly being discovered in Rubiaceae species. However, two South American species deserve special consideration: Uncaria tomentosa and Cinchona officinalis.

The Uncaria genus covers 34 species and is a particularly rich source of medicinal natural products (reviewed in Heitzman et al. [20]). Over 150 compounds have been isolated from Uncaria plants, alkaloids being the most prominent of them. Uncaria tomentosa (Willd.) DC. is endemic to central and south-America and is one of the most important medicinal plants to Peruvian populations [20]. Extracts from $U$. tomentosa have a plethora of traditional uses. Further investigations of extracts revealed activities such as immunomodulator [21, 22], antiviral [22], anti-inflammatory [23], antioxidant [20, 23] and cytostatic [24]. Tetra and pentacyclic alkaloids present in the plant extracts seem to play a major role in some of these effects $[21,24]$.

From the discovery of the New World until the mid-19 ${ }^{\text {th }}$ century, malaria was a major cause of death of European people involved in trade and colonization of tropical lands [25]. With the introduction of quinine, an active compound from Cinchona bark, the mortality fell dramatically. Quinine is an alkaloid found in Cinchona officinalis and some other Cinchona species known as "quina quina" by native populations [26]. Other antimalarial alkaloids present in Cinchona bark include quinidine, cinchonine and cinchonidine [27]. In present times, quinine-resistant strains of Plasmodium falciparum have emerged, and new drug leads to address this problem include medicinal plants [28, 29]. Alkaloids such as cephaeline (Fig. 1a) and klugine isolated from Psychotria 


\section{A}<smiles>CCC1CN2CCc3cc(OC)c(OC)cc3C2C[C@H]1CC1NCCc2cc(OC)c(OC)cc21</smiles>

B

\section{emetine}<smiles>CCC1CN2CCc3cc(OC)c(OC)cc3C2C[C@H]1CC1NCCc2cc(O)c(OC)cc21</smiles>

Fig. (1). Important active alkaloids from Psychotria species. A: The emetic isoquinoline alkaloids emetine and cephaeline from $P$. ipecacuanha, also found in P. klugii. B: The hallucinogenic dimethyl-tryptamine from $P$. viridis, one of the psychotropic constituents of ayahuasca.

klugii have shown antimalarial and antileishmanial activity [30].

Both Uncaria tomentosa and Cinchona officinalis are examples of medicinal plants discovered within traditional communities. Plants known by these people, who live in the vicinity of rich biodiversity for centuries, are interesting starting points for phytochemical screening through ethnopharmacological surveys $[1,2,31]$. Important new molecules have been discovered from medicinal plants, including the antitumorals vincristine and vinblastine from Catharanthus roseus, the antimalarial artemisin from Artemisia аппиа and the neuroactive reserpine from Rauwolfia serpentina [1].

\section{THE PSYCHOTRIA GENUS}

The genus Psychotria is one of the largest genera of flowering plants and the largest within Rubiaceae, with estimated 1000 to 1650 species distributed worldwide [32]. Psychotria species often accumulate indole alkaloids, and this trait may be important to chemosystematics, since this genus is taxonomically complex due to a lack of conspicuous morphological differentiating features [32, 33]. A number of Psychotria species yielded bioactive extracts. Some examples include antibiotic activity in extracts from $P$. microlabastra [34] and P. capensis [35] (Africa), antiviral activity in $P$. serpens [36] (China) and antiviral/antifungal and antiinflammatory activities found in $P$. hawaiiensis [37] and P. insularum [38] (Central America), respectively.

Active molecules produced by Psychotria species include naphtoquinones [39], peptides [40], benzoquinones [41], pigments [42] and alkaloids [43]. Perhaps the best known compound isolated from Psychotria species is the alkaloid emetine. Emetine (Fig. 1a) is an isoquinoline alkaloid extracted from P. ipecacuanha (ipecac) bark, a plant used by traditional communities as stimulant and "antidote to opium" [44] and in the treatment of intoxication due to its emetic effect [45]. Synthethic analogs of emetine, which have less adverse effects, are currently used in the treatment of amoebiasis [46]. Emetine is cytotoxic, inhibiting protein synthesis, and may have applications in drug-induced apoptosis [47].

Another well known Psychotria species is the one used in the preparation of the hallucinogenic drink "ayahuasca", $P$. viridis. The decoction is prepared using the plant in combination with the vine Banisteriopsis caapi. (Spruce ex Griseb). Morton (Malpighiaceae). Psychotria viridis and $B$. caapi are rich sources of the proto-alkaloid dimethyltryptamine (DMT) (Fig. 1b) and the $\beta$-carboline harmine, respectively [48]. Both substances are psychoactive, and the two have a strong synergism when administered together, possibly due to inhibitory effects of harmine on monoamine oxidase, a DMT detoxifying enzyme [49]. The recent popularization of the ayahuasca in the United States and Europe has raised several debates, from mental health issues to conflicts on drug abuse versus religious freedom [50, 51].

THE ALKALOIDS FROM PSYCHOTRIA COLORATA MÜLL. ARG

Several South American Psychotria species are used as medicinal plants by Amazon native populations [52]. An ethnobotanical survey identified species used as painkillers by "caboclos", traditional rural communities from the state of Pará, Brazil, which comprises a large fraction of 
the Amazon rainforest. The extracts of $P$. colorata showed analgesic activity, and preliminary tests pointed to alkaloids as major responsibles for the effect [53]. Further chemical investigations demonstrated the presence of several pyrrolidinoindoline and quinoline alkaloids (Fig. 2) [54], with hodgkinsine, previously isolated from Hodgkinsonia frutescens F. Muell. (Rubiaceae) [55], as a major component. Hodgkinsine is a potent analgesic, with results comparable to morphine in murine models using the hot-plate and tail-flick tests [56, 57].

Besides hodgkinsine, three other $P$. colorata pyrrolidinoindoline alkaloids, (+)-chimonanthine and the later isolated meso-chimonanthine and psychotridine [58], showed analgesic activity $[59,60]$. Interestingly, only pyrrolidinoindoline-type alkaloids, and not quinoline, gave positive results to nociceptive tests, suggesting a structure-activity relationship [58] (see Fig. 2). From the data with capsaicininduced pain models, it was suggested that the alkaloids act on opioid and glutamate receptors $[57,59,60]$.

\section{BIOACTIVE ALKALOIDS FROM SOUTHERN BRAZILIAN PSYCHOTRIA SPECIES}

The promising results with $P$. colorata motivated investigations of Southern Brazilian subtropical species. Initial screening of ethanolic extracts from Psychotria plants revealed analgesic activity in six species [61] (Fig. 3): $P$. brachyceras, $P$. carthagenensis, $P$. leiocarpa, $P$. myriantha, $P$. suterella and $P$. umbellata. All these species belong to the subgenus Heteropsychotria [33]. Among these, only $P$. carthagenensis from this region did not show positive reaction for alkaloids [62]. Curiously, P. carthagenensis is used in the preparation of ayahuasca brew in substitution to Amazonic P. viridis [62]. However, detailed chemical profiles obtained with adequate analytical facilities on $P$. carthagenensis from other regions is lacking and generalization of these results must be done with caution.

Alkaloid extracts from $P$. myriantha shoots, besides analgesic [63], revealed anti-inflammatory activity in chemotaxis assays [64]. Purification and structural elucidation yielded strictosidinic acid and a new structure, myrianthosine (Fig. 3). P. suterella Müll. Arg. leaf extracts, however, did not retain analgesic activity in the alkaloid fractions, which were highly toxic [65]. The alkaloids isolated from this species, lyaloside, strictosamide and naucletine (Fig. 3), until then had not been reported to the genus. Recently, strictosamide was found as the major component (about 98\%) of the alkaloid extract of leaves of Psychotria nuda (Cham. et Schltdl) Wawra [66]. Strictosamide was also found in Psychotria bahiensis DC. from Trinidad which yielded the bis(monoterpenoid) indole alkaloids bahienosine $\mathrm{A}$ and $\mathrm{B}$; these alkaloids incorporate two secologanin units [67].

P. leiocarpa Cham. et Schlecht is found in Argentina, Paraguay and the Southern Brazilian state of Rio Grande do Sul. The species is dominant in the understorey of subtropical semi-deciduous forests, possibly due to production of allelopathic compounds [68]. Ethanolic leaf extracts from $P$. leiocarpa yielded $N, \beta$-D-glucopyranosyl vincosamide (GPV) (Fig. 3), an unusual indole alkaloid bearing two glucose residues, as major compound [69]. The indole features a glucose residue attached to the nitrogen, an

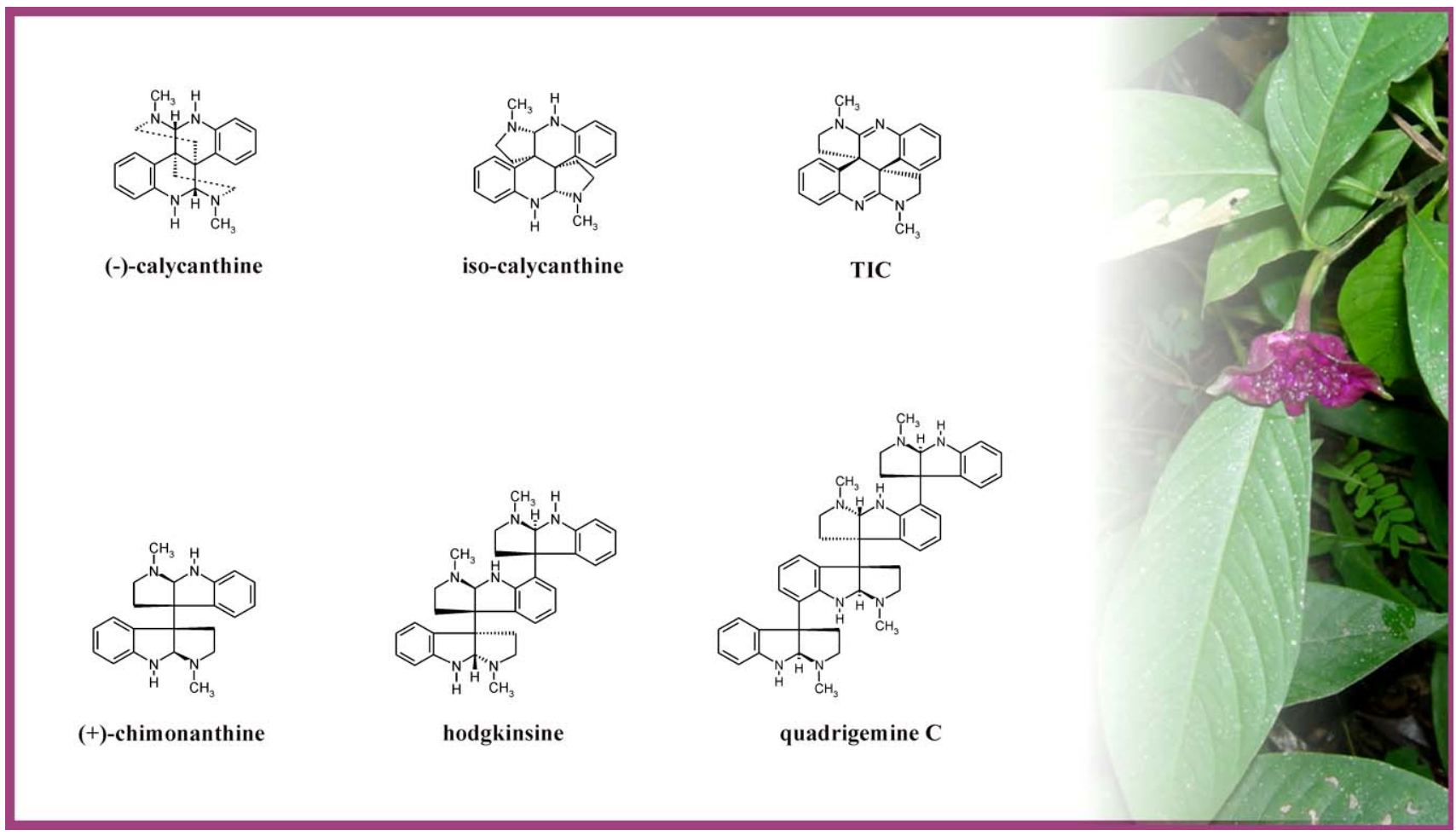

Fig. (2). Alkaloids isolated from Psychotria colorata. The upper and lower structures are quinoline and pyrrolidinoindoline alkaloids, respectively. TIC: (8-8a), (8'-8'a)-tetradehydroisocalycanthine $3 \mathrm{a}(R), 3^{\prime} \mathrm{a}(R)$. Photo modified from [87]. 


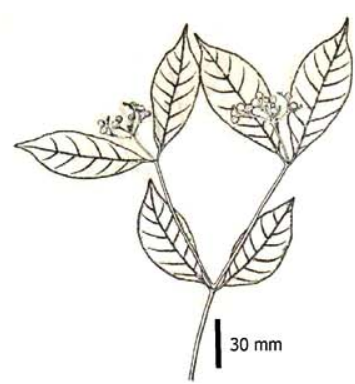

Psychotria brachyceras

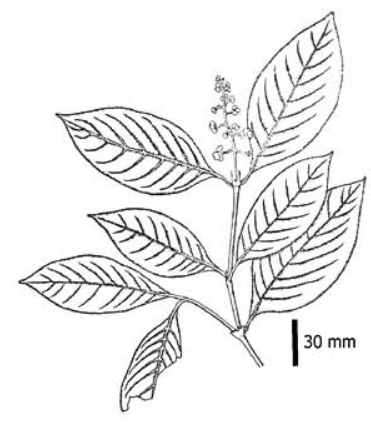

Psychotria myriantha

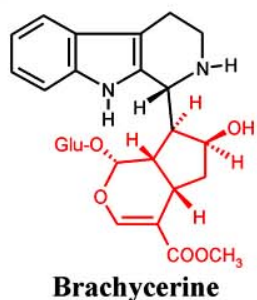

Brachycerine

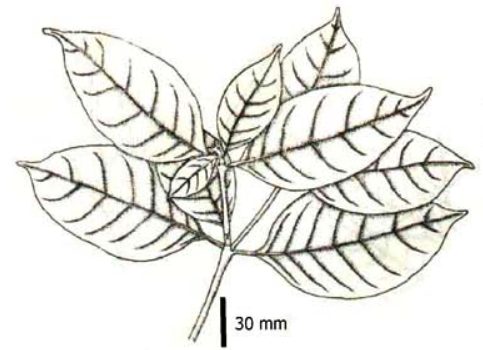

Psychotria umbellata

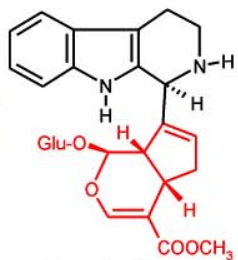

Psychollatine

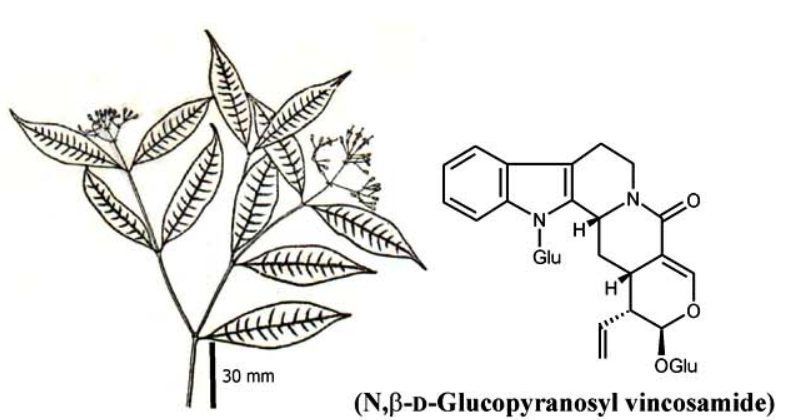

Psychotria leiocarpa

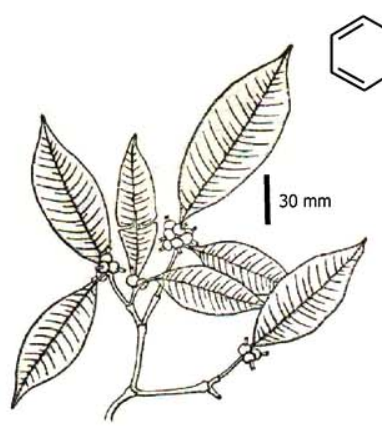

Psychotria suterella

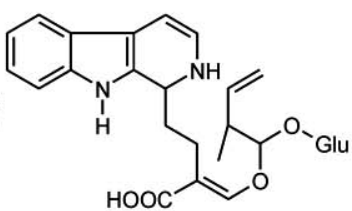

Myrianthosine

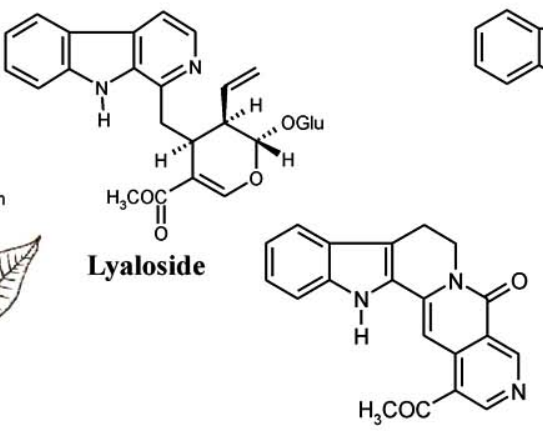

Naucletine

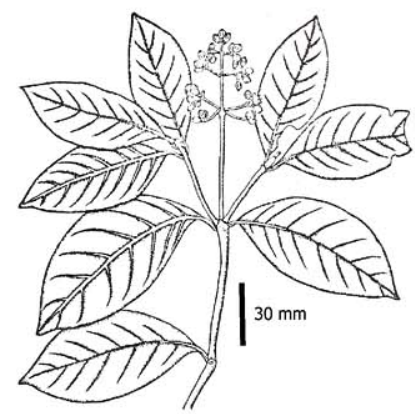

Psychotria carthagenensis

Fig. (3). Indole alkaloids from Southern Brazilian Psychotria species. The portions in red in brachycerine and psychollatine structures are residues from uncommon terpenoid precursors, which may derive from epiloganine and geniposide, respectively. Plant images adapted from [88].

uncommon configuration never before described for a monoterpenoid indole alkaloid.

From the extracts of the above six Psychotria species which gave positive results to analgesic activity, only one showed dose-dependence and reversible effect by naloxone, an opioid receptor antagonist [70]: Psychotria umbellata Vell. [61]. The leaves of $P$. umbellata accumulate the monoterpene indole alkaloid (MIA) psychollatine (Fig. 3), formerly known as umbellatine [71]. Psychollatine has also been recently isolated from Palicourea crocea, a closely related species [72] which also produces a stereoisomer of psychollatine, croceaine A [72, 73]. The alkaloid profile between the two plants may have taxonomic significance. Psychotria and Palicourea are closely related genera (P. umbellata is also referred to as Palicourea brachypoda (Müell. Arg.) L. B. Smith \& Downs and as Psychotria brachypoda (Müell. Arg.) Britton). The chemical data from both species supports the suggested fusion between the Psychotria subgenera Heteropsychotria and Palicourea into one genus [32, 33].

Psychollatine has analgesic, anxiolytic and antidepressant activities, with amnesic and sedative effects in higher doses $(100 \mathrm{mg} / \mathrm{kg})$ [74]. The alkaloid seems to be active on the serotoninergic and opioid systems. Also, both psychollatine and crude methanolic extracts from $P$. umbellata leaves showed antioxidant and antimutagenic properties in Saccharomyces cerevisae bioassays [75]. The treatments reduced growth inhibition of wild type and antioxidantenzyme-defective $S$. cerevisae strains challenged with hydrogen peroxide and superoxide anion. In addition, both psychollatine and the leaf extract inhibited $\mathrm{H}_{2} \mathrm{O}_{2}$-driven mutagenesis in $S$. cerevisae haploid lines. The alkaloid and crude extract were also effective antioxidants against hydroxyl radical in vitro [75]. 
A very similar MIA was isolated from Psychotria brachyceras Müll. Arg. [76]. The compound, named brachycerine (Fig. 3e) is a singlet oxygen [77] and superoxide (Porto et al., unpublished) quencher, and gave positive results for anti-inflammatory activity in chemotaxis assays (Henriques, A. T., unpublished). Brachycerine, as well as psychollatine, was capable of protecting $S$. cerevisae strains from oxidative stress, with higher protection against superoxide anion [78].

Both brachycerine and psychollatine are unusual MIAs. Most alkaloids of this class are derived from strictosidine, which is the product of the condensation of tryptamine and the iridoid secologanin, a reaction catalysed by strictosidine synthase [79]. However, brachycerine and psychollatine seem to be products of tryptamine condensation with epiloganin and geniposide derivatives, respectively [71, 76]. The putative pathway for brachycerine and psychollatine biosynthesis is novel, and may establish a new group of MIAs, together with croceaine A [73].

\section{REGULATION OF ALKALOID PRODUCTION IN PSYCHOTRIA SPECIES}

Despite the significant advances achieved in biochemistry, molecular biology and biotechnology of natural products, the production of active compounds in controlled conditions (i.e. cell and tissue culture) often results in economically impracticable yields [9]. Chemical synthesis or semi-synthesis of structurally complex active molecules discovered from plants is not always possible. In those cases, industry relies on the plant itself to isolate the active compound in large scale, either from plantations or naturally-occurring specimens. In both cases, isolation from adult plant tissues is often expensive and resulting in low yields [80], and in the second case, the consequences to the plant natural population and its habitat can be disastrous [81].

Molecular biology techniques, along with elicitorinduced accumulation of plant secondary metabolites, may improve bioactive molecule production in plant systems $[8,9,82,83]$. With this in mind, a series of studies were carried out in order to investigate the regulation of Psychotria alkaloids production.

The effect of white light and presence of sucrose in the culture medium on GPV content was assessed in $P$. leiocarpa seedlings. GPV production was restricted to shoots, strongly promoted by light and inhibited by exogenous sucrose, indicating the importance of photoautotrophic metabolism and photomorphogenic development for alkaloid accumulation. Also, the higher content in older seedlings (150 days) in comparison to younger ones (100 days) showed developmental control of GPV accumulation [69].

Brachycerine accumulation, in $P$. brachyceras, was restricted to shoots. The highest concentration occurred in inflorescences $(0.3 \%)$, followed by fully expanded leaves $(0.18 \%)$, stems $(0.13 \%)$, young leaves $(0.12 \%)$ and fruit pulp $(0.04 \%)$ [84]. The leaf alkaloid content in field-grown trees showed seasonal variation in some years, with lower concentrations in the summer. In vitro cultured seedlings 14 days after radicle emission accumulated brachycerine contents comparable to those of adult plants [84].

Leaf brachycerine content in cuttings was responsive to several stimuli. Mechanical damage or jasmonic acid, an herbivory-related hormone [85], induced brachycerine accumulation (Gregianini et al., 2004) [84], suggesting a deterrent role for the alkaloid. However, no toxic effect was detected in generalist herbivore bioassays (Porto et al., unpublished data). Ultraviolet (UV) radiation, both in UV-C (254 nm, germicidal lamp) and UV-B (280-315 nm) ranges, induced up to 10-fold brachycerine accumulation in leaves of cuttings [77]. The antioxidant properties of brachycerine and its strong UV-regulation indicate a protective role for the alkaloid in planta.

Differently from brachycerine, psychollatine accumulation in $P$. umbellata cuttings is rather insensitive to the treatments described. However, the plant naturally accumulates a relatively high amount of psychollatine (1-4\% of dry weight) [9]. An in vitro somatic embryogenesis protocol was established from cultured rhizogenic callus, and, after three months of acclimatization, psychollatine-accumulating plants were obtained with alkaloid contents similar to those found in adult plants; in addition, the capacity to produce the alkaloid was closely associated with the differentiation of somatic embryo shoots [86].

The alkaloids of Psychotria species from Southern Brazil represent relatively primitive structures compared to the bisindolic alkaloids of the best studied species in monoterpene indole alkaloid metabolism, Catharanthus roseus. However, these simpler Psychotria alkaloids also display interesting pharmacological properties. The presence of new structures, such as the $N$-glycosylated GPV and the non-secologanin derived terpene moieties of brachycerine and psychollatine highlight the prominent chemical diversity in this genus. Other features that are common to most of the described alkaloids of Psychotria include the retention of glucose residues (which may favor solubility in aqueous environments), antioxidant capacity, the requirement of differentiated shoots for active alkaloid production, and the accumulation in reproductive structures.

\section{CONCLUDING REMARKS}

The alkaloids from Psychotria colorata (Fig. 2) [87] were a direct result of ethnopharmacological surveys in the Amazonian region. The simple expansion of chemical investigations to include related species from a different biome (chemotaxonomical survey of Psychotria species of Southern Brazil, [88]), involving plants that even lack popular names, revealed several other bioactive alkaloids. Further research on the biological activity of these new compounds, elucidation of their biosynthetic origins and regulation of production, along with studies on plant propagation, may convert relatively unknown species in viable sources of new drugs.

\section{REFERENCES}

[1] Gurib-Fakim, A. Medicinal plants: traditions of yesterday and drugs of tomorrow. Mol. Aspects Med., 2006, 27, 1-93. 
[2] Balunas, M. J.; Kinghorn, A. D. Drug discovery from medicinal plants. Life Sci., 2005, 78, 431-441.

[3] Hartmann, T. From waste products to ecochemicals: fifty years research on plant secondary metabolism. Phytochemistry, 2007, 68, 2831-2846.

[4] Harvey, A. Strategies for discovering drugs from previously unexplored natural products. Drug Discov. Today, 2000, 5(7), 294300 .

[5] Newman, D. J.; Cragg, G. M. Natural products as sources of new drugs over the last 25 years. J. Nat. Prod., 2007, 70, 461-477.

[6] Gassner, N. C.; Tamble, C. M.; Bock, J. E.; Cotton, N.; White, K. N.; Tenney, K.; Onge, R. P. S.; Proctor, M. J.; Giaever, G.; Nislow, C.; Davis, R. W.; Crews, P.; Holman, T. R.; Lockey, R. S. Accelerating the discovery of biologically active small molecules using a high-throughput yeast halo assay. J. Nat. Prod., 2007, 70, 383390.

[7] Petersen, M. Current status of metabolic phytochemistry. Phytochemistry, 2007, 68, 2847-2860.

[8] Oksman-Caldentey, K.; Inzé, D. Plant cell factories in the postgenomic era: new ways to produce designer secondary metabolites. Trends Plant Sci., 2004, 9(9), 433-440.

[9] Pasquali, G.; Porto, D. D.; Fett-Neto, A. G. Metabolite engineering of cell cultures versus whole plant complexity in production of bioactive monoterpene indole alkaloids: recent progress related to old dilemma. J. Biosci. Bioeng., 2006, 101(4), 287-296.

[10] Mongrand, S.; Badoc, A.; Patouille, B.; Lacomblez, C.; Chavent, M.; Bessoule, J. J. Chemotaxonomy of the Rubiaceae family based on leaf fatty acid composition. Phytochemistry, 2005, 66(5), 549559.

[11] Ashihara, H.; Sano, H.; Crozier, A. Caffeine and related purine alkaloids: Biosynthesis, catabolism, function and genetic engineering. Phytochemistry, 2008, 69, 841-856.

[12] Deeni, Y. Y.; Hussain, H. S. N. Screening for antimicrobial activity and for alkaloids of Nauclea latifolia. J. Ethnopharmacol., 1991, 35, 91-96.

[13] Cardoso, C. L.; Castro-Gamboa, I.; Silva, D. H. S.; Furlan, M.; Epifanio, R. A.; Pinto, A. C.; Rezende, C. M.; Lima, J. A.; Bolzani, V. S. Indole glucoalkaloids from Chimarrhis turbinata and their evaluation as antioxidant agents and acetylcholinesterase inhibitors. J. Nat. Prod., 2004, 67(11), 1882-1885.

[14] Takayama, H. Chemistry and pharmacology of analgesic indole alkaloids from the Rubiaceous plant, Mytragina speciosa. Chem. Pharm. Bull., 2004, 52(8), 916-928.

[15] Chan-Blanco, Y.; Vaillant, F.; Perez, A. M.; Reynes, M.; Brillouet, J.; Brat, P. The noni fruit (Morinda citrifolia L.): a review of agricultural research, nutritional and therapeutical properties. J.Food Compos. Anal., 2006, 19, 645-654.

[16] Tao, J.; Morikawa, T.; Ando, S.; Matsuda, H.; Yoshikawa, M. Bioactive constituents from chinese natural medicines. XI. Inhibitors of NO production and degranulation in RBL-2H3 from Rubia yunnanensis: Structures of Rubianosides II, III and IV, Rubianol-g, and Rubianthraquinone. Chem. Pharm. Bull., 2003, 51(6): 654-662.

[17] Wu, T.; Lin, D.; Shi, L.; Damu, A. G.; Kuo, P.; Kuo, Y. Cytotoxic anthraquinones from the stems of Rubia wallichiana Decne. Chem. Pharm. Bull., 2003, 51(8): 948-950.

[18] Lee, J.; Hitotsuyanagi, Y.; Fukaya, H.; Kondo, K.; Takeya, K. New cytotoxic byciclic hexapeptides, RA-XXIII and RA-XXIV, from Rubia cordifolia L. Chem. Pharm. Bull., 2008, 56(5): 730-733.

[19] Bokesch, H. R.; Pannel, L. K.; Cochran, P. K.; Sowder, R. C.; McKee, T. C.; Boyd, M. R. A novel anti-HIV macrocyclic peptide from Palicourea condensata. J. Nat. Prod., 2001, 64(2), 249-250.

[20] Heitzman, M. E.; Neto, C. C.; Winiarz, E.; Vaisberg, A. J.; Hammond, G. B. Ethnobotany, phytochemistry and pharmacology of Uncaria (Rubiaceae). Phytochemistry, 2005, 66, 5-29.

[21] Keplinger, K.; Laus, G.; Wurm, M.; Dierich, M. P.; Teppner, H. Uncaria tomentosa (Willd.) DC. - Ethnomedicinal use and new pharmacological, toxicological and botanical results. J. Ethnopharmacol., 1999, 64, 23-34.

[22] Reis, S. R. I. N.; Valente, L. M. M.; Sampaio, A. L.; Siani, A. C.; Gandini, M.; Azeredo, E. L.; D’Avila, L. A.; Mazzei, J. L.; Henriques, M. G. M.; Kubelka, C. F. Immunomodulating and antiviral activities of Uncaria tomentosa on human monocytes infected with Dengue Virus-2. Int. Immunopharmacol., 2008, 8, 468-476.

[23] Amaral, S.; Mira, L.; Nogueira, J. M. F.; Silva, A. P.; Florêncio, M. H. Plant extracts with anti-inflammatory properties - A new approach for characterization of their bioactive compounds and establishment of structure-antioxidant activity relationships. Bioorgan. Med. Chem., 2009, 17, 1876-1883.

[24] Kurás, M.; Pilarski, R.; Nowakowska, J.; Zobel, A.; Brzost, K.; Antosiewicz, J.; Gulewicz, K. Effect of alkaloid-free and alkaloidrich preparations from Uncaria tomentosa bark on mitotic activity and chromosome morphology evaluated by Allium test. J. Ethnopharmacol., 2009, 121, 140-147.

[25] Carter, R.; Mendis, K. M. Evolutionary and historical aspects of the burden of malaria. Clin. Microbiol. Rev., 2002, 15(4), 564594.

[26] Kinsley-Scott, T. R.; Norton, S. A. Useful plants in dermatology. VII: Cinchona and antimalarials. J. Am. Acad. Dermatol., 2003, 49 499-502.

[27] Druilhe, P.; Brandicourt, O.; Chongsuphajaisiddhi, T.; Berthe, J. Activity of a combination of three Cinchona bark alkaloids against Plasmodium falciparum in vitro. Antimicrob. Agents Ch., 1988, 32(2), 250-254.

[28] Kvist, L. P.; Christensen, S. B.; Rasmussen, H. B.; Mejia, K.; Gonzales, A. Identification and evaluation of Peruvian plants used to treat malaria and leishmaniasis. J. Ethnopharmacol., 2006, 106, 390-402.

[29] Bourdy, G.; Willcox, M. L.; Ginsburg, H.; Rasoanaivo, Ph.; Graz, B.; Deharo, E. Ethnopharmacology and malaria: new hypothetical leads or old efficient antimalarials? Int. J. Parasitol., 2008, 38, 3341 .

[30] Muhammad, I.; Dunbar, D. C.; Khan, S. I.; Tekwani, B. L.; Bedir, E.; Takamatsu, S.; Ferreira, D.; Walker, L. A. Antiparasitic alkaloids from Psychotria klugii. J. Nat. Prod., 2003, 66, 962-967.

[31] Soh, P. N.; Benoit-Vical, F. Are West African plants a source of future antimalarial drugs? J. Ethnopharmacol., 2007, 114, 130-140.

[32] Nepkroeff, M.; Bremer, B.; Systma, K. J. Reorganization of the genus Psychotria and tribe Psychotrieae (Rubiaceae) inferred from ITS and $r b c L$ sequence data. Syst. Bot., 1999, 24(1), 5-27.

[33] Lopes, S.; von Poser, G. L.; Kerber, V. A.; Farias, F. M.; Konrath, E. L.; Moreno, P.; Sobral, M. E.; Zuanazzi, J. A. S.; Henriques, A. T. Taxonomic significance of alkaloids and iridoid glucosides in the tribe psychotrieae (Rubiaceae). Biochem. Syst. Ecol., 2004, 32, 1187-1195.

[34] Khan, M. R.; Kihara, M.; Omoloso, A. D. Antimicrobial activity of Psychotria microlabastra. Fitoterapia, 2001, 72, 818-821.

[35] McGaw, L. J.; Jäger, A. K.; van Staden, J. Antibacterial, anthelmintic and anti-amoebic activity in South African medicinal plants. J. Ethnopharmacol., 2000, 72, 247-263.

[36] Kuo, Y.; Chen, C.; Tsai, W.; Ho, Y. Regulation of herpes simplex virus type 1 replication in Vero cells by Psychotria serpens: relationship to gene expression, DNA replication, and protein synthesis. Antiviral Res., 2001, 51, 95-109.

[37] Locher, C. P.; Burch, M. T.; Mower, H. F.; Berestecky, J.; Davis, H.; van Poel, B.; Lasure, A.; Berghe, D. A. V.; Vlietinck, A. J. Anti-microbial activity and anti-complement activity of extracts obtained from selected Hawaiian medicinal plants. J. Ethnopharmacol., 1995, 49, 23-32.

[38] Dunstan, C. A.; Noreen, Y.; Serrano, G.; Cox, P. A.; Perera, P.; Bohlin, L. Evaluation of some Samoan and Peruvian medicinal plants by prostaglandin biosynthesis and rat ear oedema assays. $J$. Ethnopharmacol., 1997, 57, 35-56.

[39] Hayashi, T.; Smith, F. T.; Lee, K. H. Antitumor agents. 89. Psychorubrin, a new cytotoxic naphtoquinone from Psychotria rubra and its structure-activity relationships. J. Med. Chem., 1987, 30(11), 2005-2008.

[40] Witherup, K. M.; Bogusky, M. J.; Anderson, P. S.; Ramjit, H.; Ransom, R. W.; Wood, T.; Sardana, M. Cyclopsychotride A, a biologically active, 31-residue cyclic peptide isolated from Psychotria longipes. J. Nat. Prod., 1994, 57(12), 1619-1625.

[41] Solis, P. N.; Lang'at, C.; Gupta, M. P.; Kirby, G. C.; Warhurst, D. C.; Phillipson, J. D. Bio-active compounds from Psychotria camponutans. Planta Med., 1995, 61, 62-65. 
[42] Glinski, J. A.; David, E.; Warren, T. C.; Hansen, G.; Leonard, S. F.; Pitner, P.; Pav, S.; Arvigo, R.; Balick, M. J.; Panti, E.; Grob, P. $\mathrm{M}$. Inactivation of cell surface receptors by pheophorbide a, a green pigment isolated from Psychotria acuminata. Photochem. Photobiol., 1995, 62(1), 144-150.

[43] Beretz, A.; Roth-Georger, A.; Corre, G.; Kuballa, B.; Anton, R.; Cazenave, J. Polyindolinic alkaloids from Psychotria forsteriana. Potent inhibitors of the aggregation of human platelets. Planta Med., 1985, 51, 300-303.

[44] Giorgetti, M.; Negri, G.; Rodrigues, E. Brazilian plants with possible action on the central nervous system - A study of historical sources from the 16th to 19th century. J. Ethnopharmacol., 2007, 109, 338-347.

[45] Hasegawa, M.; Sasaki, T.; Sadakane, K.; Tabuchi, M.; Takeda, Y.; Kimura, M.; Fujii, Y. Studies for the emetic mechanism of Ipecac Syrup (TJN-119) and its active components in ferrets: involvement of 5-hydroxytryptamine receptors. Jpn. J. Pharmacol., 2002, 89, 113-119.

[46] Mangaña-García, M.; Arista-Viveros, A. Cutaneous amebiasis in children. Pediatr. Dermatol., 2008, 10(4): 352-355.

[47] Möller, M.; Herzer, K.; Wenger, T.; Herr, I.; Wink, M. The alkaloid emetine as a promising agent for the induction and enhancement of drug-induced apoptosis in leukemia cells. Oncol. Rep., 2007, 18, 737-744.

[48] Freedland, C. S.; Mansbach, R. S. Behavioral profile of constituents in ayahuasca, an Amazonian psychoactive plant mixture. Drug Alcohol Depend., 1999, 54, 183-194.

[49] Buckholtz, N. S.; Boggan, W. O. Monoamine oxidase inhibition in brain and liver produced by $\beta$-carbolines: structure activity relationships and substrate specificity. Biochem. Pharmacol., 1977, 26, 1991-1996.

[50] Santos, R. G.; Landeira-Fernandez, J.; Strassman, R. J.; Motta, V.; Cruz, A. P. M. Effects of ayahuasca on psychometric measures of anxiety, panic-like and hopelessness in Santo Daime members. $J$. Ethnopharmacol., 2007, 112, 507-513.

[51] Tupper, K. W. The globalization of ayahuasca: Harm reduction or benefit maximization? Int. J. Drug Policy, 2008, 19, 297-303.

[52] Sanz-Biset, J.; Campos-de-la-Cruz, J.; Epiquién-Rivera, M. A.; Cañigueral, S. A first survey on the medicinal plants of the Chazuta valley (Peruvian Amazon). J. Ethnopharmacol., 2009, 122, 333362 .

[53] Elisabetsky, E.; Amador, T. A.; Albuquerque, R. R.; Nunes, D. S.; Carvalho, A. C. T. Analgesic activity of Psychotria colorata (Willd. ex R. \& S.) Muell. Arg. alkaloids. J. Ethnopharmacol., 1995, 48, 77-83.

[54] Verotta, L.; Pilati, T.; Tatò, M.; Elisabetsky, E.; Amador, T. A.; Nunes, D. S. Pyrrolidinoindoline alkaloids from Psychotria colorata. J. Nat. Prod., 1998, 61, 392-396.

[55] Fridrichsons, J.; Mackay, M. F.; Mathieson, A. M. The absolute molecular structure of hodgkinsine. Tetrahedron, 1974, 30(1), 8592.

[56] Kodanko, J. J.; Hiebert, S.; Peterson, E. A.; Sung, L.; Overman, L. E.; Linck, V. M.; Goerck, G. C.; Amador, T. A.; Leal, M. B.; Elisabetsky, E. Synthesis of all-low energy stereoisomers of the tris (pyrrolidinoindoline) alkaloid hodgkinsine and preliminary assessment of their antinociceptive activity. J. Org. Chem., 2007, 72(21), 7909-7914.

[57] Amador, T. A.; Verotta, L.; Nunes, D. S.; Elisabetsky, E. Antinociceptive profile of hodgkinsine. Planta Med., 2000, 66, 770772 .

[58] Verotta, L.; Peterlongo, F.; Elisabetsky, E.; Amador, T. A.; Nunes, D. S. High-performance liquid chromatography - diode array detection - tandem mass spectrometry analyses of the alkaloid extracts of Amazon Psychotria species. J. Chromatogr. A, 1999, 841: 165176.

[59] Verotta, L.; Orsini, F.; Sbacchi, M.; Scheildler, M. A.; Amador, T. A.; Elisabetsky, E. Synthesis and antinociceptive activity of chimonanthines and pyrrolidinoindoline-type alkaloids. Bioorg. Med. Chem., 2002, 10, 2133-2142.

[60] Amador, T. A.; Verotta, L.; Nunes, D. S.; Elisabetsky, E. Involvement of NMDA receptors in the analgesic properties of psychotridine. Phytomedicine, 2001, 8(3), 202-206.
[61] Leal, M. B. Thesis, Universidade Federal do Rio Grande do Sul, Brazil, 1994.

[62] Leal, M. B.; Elisabetsky, E. Absence of alkaloids in Psychotria carthagenensis Jacq. (Rubiaceae). J. Ethnopharmacol., 1996, 54, 37-40.

[63] Both, F. L.; Farias, F. M.; Nicoláo, L. L.; Misturini, J.; Henriques, A. T.; Elisabetsky, E. Avaliação da atividade analgésica de extratos alcaloídicos de espécies de Psychotria. Rev. Bras. Plant. Med., 2002, 5(1): 41-45.

[64] Simões-Pires, C. A.; Farias, F. M.; Marston, A.; Queiroz, E. F.; Chaves, C. G.; Henriques, A. T.; Hostettmann, K. Indole monoterpenes with antichemotactic activity from Psychotria myriantha: Chemotaxonomic significance. Nat. Prod. Comm., 2006, 1(12), 1101-1106.

[65] Santos, L. V.; Fett-Neto, A. G.; Kerber, V. A.; Elisabetsky, E.; Quirion, J. P.; Henriques, A. T. Indole monoterpene alkaloids from leaves of Psychotria suterella Müll. Arg. (Rubiaceae). Biochem. Syst. Ecol., 2001, 29, 1185-1187.

[66] Farias, F. M.; Konrath, E. L.; Zuanazzi, J. A.; Henriques, A. T. Strictosamide from Psychotria nuda (Cham. Et Schltdl) Wawra (Rubiaceae). Biochem. Syst. Ecol., 2009, 36, 919-920.

[67] Paul, J. H. A.; Maxwell, A. R.; Reynolds, W. F. Novel bis(monoterpenoid) indole alkaloids from Psychotria bahiensis. J. Nat. Prod., 2003, 66, 752-754.

[68] Corrêa, L. R.; Soares, G. L. G.; Fett-Neto, A. G. Allelopathic potential of Psychotria leiocarpa, a understory species of subtropical forests. S. Afr. J. Bot., 2008, 74(4), 583-590.

[69] Henriques, A. T.; Lopes, S. O.; Paranhos, J. T.; Gregianini, T. S.; Poser, G. L. V.; Fett-Neto, A. G.; Schripsema, J. $N$ - $\beta$-D-Glucopyranosyl vincosamide, a light regulated indole alkaloid from the shoots of Psychotria leiocarpa. Phytochemistry, 2004, 65, 449454.

[70] Kayser, V.; Guilbaud, G. Differential effect of various doses of morphine and naloxone on two nociceptive tests thresholds in arthritic and normal rats. Pain, 1990, 41(3): 353-363.

[71] Kerber, V. A.; Passos, C. S.; Verli, H.; Fett-Neto, A. G.; Quirion, J. P.; Henriques, A. T. Psychollatine, a glucosidic monoterpene indole alkaloid from Psychotria umbellata. J. Nat. Prod., 2008, 71, 697-700.

[72] Narine, L. L.; Maxwell, A. R. Monoterpenoid indole alkaloids from Palicourea crocea. Phytochem. Lett., 2009, 2, 34-36.

[73] Düsman, L.T.; Jorge, T. C. M.; Souza, M. C.; Eberlin, M. N.; Meurer, E. C.; Bocca, C. C.; Basso, E. A.; Sarragiotto, M. H. Monoterpene indole alkaloids from Palicourea crocea. J. Nat. Prod., 2004, 67(11): 1886-1888.

[74] Both, F. L.; Meneghini, L.; Kerber, V. A.; Henriques, A. T.; Elisabetsky, E. Psychopharmacological profile of the alkaloid psychollatine as a $5 \mathrm{HT} 2_{\mathrm{A} / \mathrm{C}}$ serotonin modulator. J. Nat. Prod., 2005, 68, 374-380.

[75] Fragoso, V.; Nascimento, N. C.; Moura, D. J.; Silva, A. C. R.; Richter, M. F.; Saffi, J.; Fett-Neto, A. G. Antioxidant and antimutagenic properties of the monoterpene indole alkaloid psychollatine and the crude foliar extract of Psychotria umbellata Vell. Toxicol. in Vitro, 2008, 22, 559-566.

[76] Kerber, V. A.; Gregianini, T. S.; Paranhos, J. T.; Schwambach, J.; Farias, F.; Fett, J. P.; Fett-Neto, A. G.; Zuanazzi, J. A.; Quirion, J. P.; Elisabetsky, E.; Henriques, A. T. Brachycerine, a novel monoterpene indole alkaloid from Psychotria brachyceras. J. Nat. Prod., 2001, 64, 677-679.

[77] Gregianini, T. S.; Silveira, V. C.; Porto, D. D.; Kerber, V. A.; Henriques, A. T.; Fett-Neto, A. G. The alkaloid brachycerine is induced by ultraviolet radiation and is a singlet oxygen quencher. Photochem. Photobiol., 2003, 78(5), 470-474.

[78] Nascimento, N. C.; Fragoso, V.; Moura, D. J.; Silva, A. C. R.; Fett-Neto, A. G.; Saffi, J. Antioxidant and antimutagenic effects of the crude foliar extract and the alkaloid Brachycerine of Psychotria brachyceras. Environ. Mol. Mutagen., 2007, 48(9), 728-734.

[79] Ziegler, J.; Facchini, P. J. Alkaloid biosynthesis: metabolism and trafficking. Annu. Rev. Plant Biol., 2008, 59, 735-69.

[80] Rao, S. R.; Ravishankar, G. A. Plant cell cultures: chemical factories of secondary metabolites. Biotechnol. Adv., 2002, 20(2), 101153. 
[81] Koo, B.; Wright, B. D. The role of biodiversity products as incentives for conserving biological diversity: some instructive examples. Sci. Total Environ., 1999, 240, 21-30.

[82] Dixon, R. A. Engineering of plant natural product pathways. Curr. Opin. Plant Biol., 2005, 8, 329-336.

[83] Zhang, W. J.; Björn, L. O. The effect of ultraviolet radiation on the accumulation of medicinal compounds in plants. Fitoterapia, 2009, 80 (4), 207-218.

[84] Gregianini, T. S.; Porto, D. D.; Nascimento, N. C.; Fett, J. P.; Henriques, A. T.; Fett-Neto, A. G. Environmental and ontogenetic control of accumulation of brachycerine, a bioactive indole alkaloid from Psychotria brachyceras. J. Chem. Ecol., 2004, 30(10), 20232036.
[85] Wasternack, C. Jasmonates: an update in biosynthesis, signal transduction and action in plant stress response, growth and development. Ann. Bot-(Lond)., 2007, 100, 681-697.

[86] Paranhos, J. T.; Fragoso, V.; Henriques, A. T.; Ferreira, A. G.; FettNeto, A. G. Regeneration of Psychotria umbellata and production of the analgesic indole alkaloid umbellatine. Tree Physiol., 2005 , 25, 251-255.

[87] Royal Botanic Gardens, Kew. Images. http://www.kew.org/science/ tropamerica/neotropikey/families/images/Rubiaceae/Psychotria_col orata_5.jpeg.png (accessed April 23, 2009).

[88] Dillenburg, C. R. Thesis, Universidade Federal do Rio Grande do Sul, Brazil, 1978.

(C) Porto et al.; Licensee Bentham Open.

This is an open access article licensed under the terms of the Creative Commons Attribution Non-Commercial License (http://creativecommons.org/licenses/by$\mathrm{nc} / 3.0 /$ ) which permits unrestricted, non-commercial use, distribution and reproduction in any medium, provided the work is properly cited. 